\title{
Financial Inclusion as An Antecedent Of Agility Strategic Diversification Investment (ASDI) In Maintaining Banking Financial Performance
}

\author{
Yuyun Ristianawati ${ }^{1}$, Setyo Budi Hartono ${ }^{2}$ \\ Faculty of Economic and Business, Sultan Agung Islamic University, Semarang, Indonesia ${ }^{1}$, Faculty \\ of Economics and Business Islam, State Islamic University Walisongo, Semarang, Indonesia ${ }^{2}$ \\ \{yuyun.r@std.unissula.ac.id\}
}

\begin{abstract}
This study aims to understand new trends that disrupt the relationship between financial inclusion and banking financial performance. In order to be able to link financial inclusion with banking financial performance, Agility Strategic Diversification Investment (ASDI) is needed in carrying out the resource vision and portfolio integration. The method consists of making two theories into one integration, wherein the two theories are combined based on a logical connection. ASDI is used to mediate financial inclusion in forecasting bank financial performance. As a result, this relationship can be correlated by ASDI which can be an intervention to improve bank financial performance in situations when financial inclusion does not directly support banking activities.
\end{abstract}

Keywords: Financial inclusion; Agility Strategic Diversification Investment; Financial Performance.

\section{Introduction}

As a discipline, the concentration of financial management is to use resources efficiently to ensure short-term profitability for competitive advantage, while maintaining long-term success on new skills in exploring markets that have not been explored by other companies (Afacan Findıklı et al., 2015). From the many studies that have been carried out, capabilities and disabilities are important factors in sustainable profit to filter the strengths and weaknesses of the company by separating opportunities and threats (Porter, 1980; Porter and Advantage, 1985) or creating hybrid strategies from them (Hofer and Schendel, 1978). As a result of an approach that focuses on capabilities and weaknesses, observations of opportunities and threats from inside or outside the company become information on the competitiveness of the business environment (Lamb, 1984).

The problem of financial inclusion is the low level of conformity between the design of innovations in the designation of business situations, in fact the problems that must be faced by companies are often not followed by the development of new knowledge on the company's products (Shahid et al., 1997). Ali (2019) who revealed a study of financial inclusion in poor countries in Africa found that existing banks did not open access for some citizens in that country. This has an impact on unsatisfactory results and cannot develop the bank's financial performance. Economic activity in the country did not develop due to the inclusion built by banks in limiting access to finance for the wider community. 
Strategic agility behavior and awareness of organizational transformation are important in overcoming unfavorable situations. Acting fast and innovating in a rapidly changing environment will enable companies to have significantly improved levels of financial performance. This action can reflect the company in formulating strategies, especially on the agility factor in adjusting to a very dynamic environment. A flexible company can adapt to an uncertain environment and will always thrive on it.

In essence, if the company can control its agility as a strategic, then it will also be able to develop various strategies for growth. The agility strategy will discuss how companies can adjust their diversification in terms of product and process adjustments in various services at the level of the company structure which is certainly intended to achieve sustainability (Tallon and Pinsonneault, 2011). Organizational agility in creating innovation opportunities for internal processes is a solution that can develop for the company's performance (Aranz et al., 2019; Damanpour, 2011).

The impact of agility on innovation can be made to meet customer needs, gain new markets, reduce costs, increase production flexibility, and more. Thus, it is absolutely essential for a company to develop a strategy for its innovation agility in pursuing the company's performance proposition (Sariol and Abebe, 2017; Wong et al., 2011).

\section{Literature Review}

\subsection{Financial Inclusion}

The scope of financial inclusion is that some citizens and businesses are excluded from accessing and using financial services. Researchers at the World Bank (eg Demirgüç-Kunt \& Klapper, 2012; World Bank, 2014, 2017) make an important distinction between voluntary and involuntary exclusion. Voluntary exclusion occurs when an individual or company places religion, conditions and culture as the reasons for the inclusion. On the other hand, forced exclusion is mainly due to the economic downturn, which makes him a high-risk individual by many banking and financial services organizations.

Sarma (2008) reveals that the inclusion of some disadvantaged communities is the strongest reason for financial organizations. This is termed a multidimensional condition on the treatment of some individuals who are excluded and indeed avoided in their financial system. Financial institutions consider this appropriate for them to do as a consequence of the inclusion of risks faced in terms of the economic capacity of each individual. Cheston et al., (2016, p.13) conclusively classify financial inclusion as follows:

a. Access to various financial services, including credit, savings, insurance and payments.

b. Good quality in the sense of a fair and reasonable price, appropriate and dignified;

c. The Client's financial ability to inform the Client and make sound money management decisions.

d. Financial services for marginal groups.

e. Diverse and competitive market with diverse service providers, strong financial infrastructure and clear regulatory framework. 


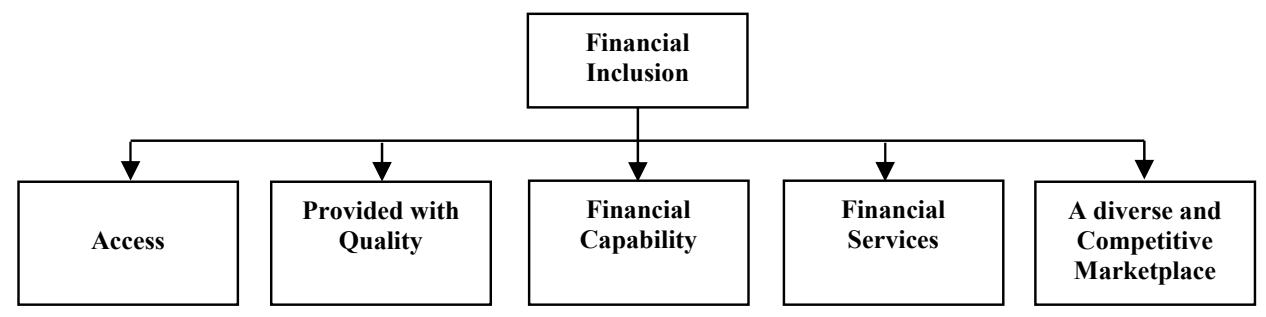

Fig 1. Financial Inclusion Demensi

\subsection{Agility Strategic Diversification Investment}

Ristianawati et al., (2021) based on the study of resource-based theory and portfolio theory, the derivation of the two theories can lead to the application of strategic agility in building investment diversification. Implementation of strategic agility is carried out through product innovation and information innovation in solving investment diversification problems (integration of product and information expansion, risk tolerance innovation, and investment alignment innovation).
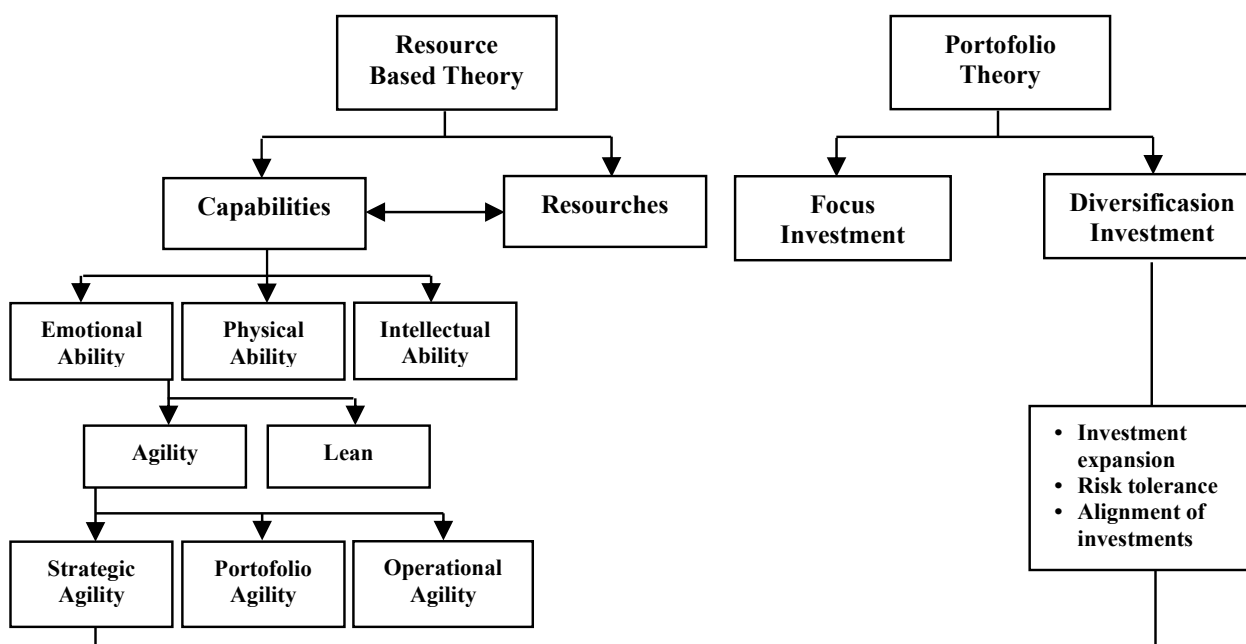

Investment

Investment

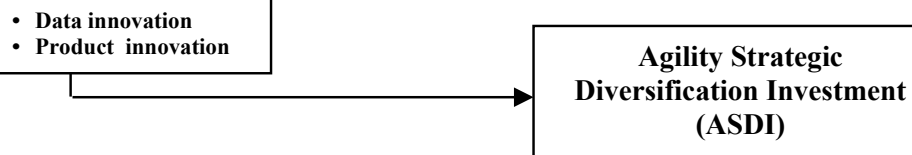

Fig 2. Derivation of Agility Strategic Diversification Investment (ASDI). 
Product and information expansion strategy that leads to risk-tolerant innovation so that it can be used in investment alignment, as an effort to improve financial services. The application of ASDI in improving banking financial services will open access for customers and trigger the bank's financial performance (Ristianawati et al., 2021).

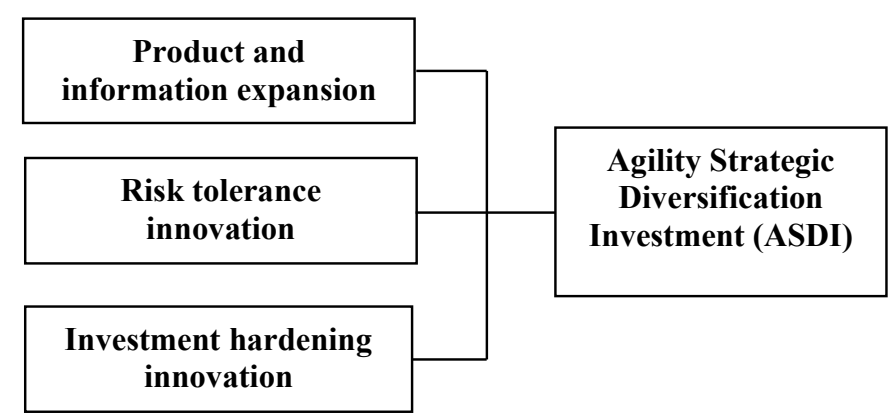

Fig 3. Agility Strategic Diversification Investment Proposition.

\subsection{Financial Performance}

If you look at the basis of resource theory, the inclusion in the company must be seen as a reversal in winning the competition with other companies (Barney, 1991). In the banking world, inclusion problems occur in information asymmetry in verifying data in financial decision making. In this case, the inclusion condition leads to the ability of banks to present data with valid quality, while on the customer side, it will provide much more information that is not in accordance with economic conditions to benefit from bank disbursements. The problem of inclusion becomes interesting if banks can overcome it and become a trend to signal their performance (Sapiro, 1983; Caruana et al., 2018).

This signal indicates a solution to the inclusion problems facing banks (Fombrun and Shanley, 1990) and leads the opinions of customers and stakeholders to the development of internal processes (Fombrun, 2001; Fombrun et al., 2015). This positive signal or trend in inclusion can be developed in improving the financial performance of banks by reducing negotiation costs and reducing uncertainty for customers and other stakeholders (Podolny, 1993). Handling inclusion problems should use two perceptions, namely on banking perceptions by increasing the persuasive approach, and customer perceptions on the economic stability capability approach that they are able to grasp and develop.

Thus, the view of financial inclusion in the banking world can be drawn with empirical evidence that has been suggested by researchers to have an impact on financial performance. Researchers such as Deephouse, (2000); Roberts and Dowling, (2002); Eberl and Schwaiger, (2005); Anderson and Smith, (2006); Alvarado-Vargas, (2013); Hall and Lee, (2014); Raithel and Schwaiger, (2015); Chen, (2016); Castilla-Polo et al., (2018); Kaur and Singh, (2018); Santiago et al., (2019) have tested the company's ability to overcome financial inclusion problems in improving financial performance. 


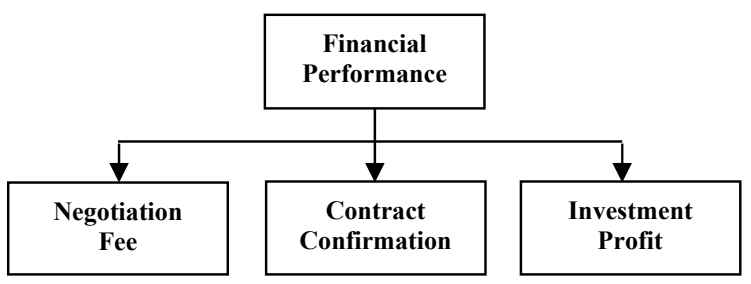

Fig 4. Dimensions of Financial Performance.

\subsection{Empirical Thinking Framework}

The framework developed in this study is to include the Agility Strategic Diversification Investment (ASDI) variable as a mediation on the relationship between financial inclusion and financial performance. This mediation serves as a bridge between the two variables, as well as serves as a signal for banking companies in overcoming inclusion problems.

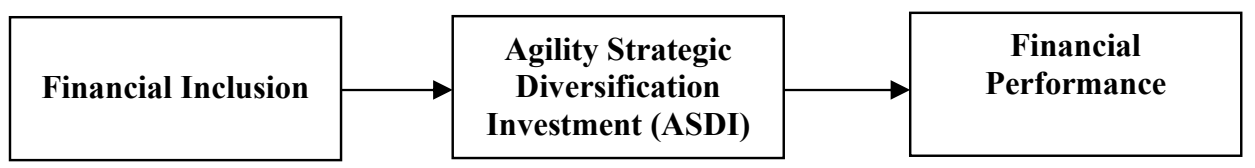

Fig 5. Empirical Framework..

\section{Methodology}

Hartono et al., (2019), this research belongs to the type of conceptual research from the derivation of two basic theories. Agility Strategic Diversification Investment (ASDI) uses the derivation of two fundamental theories (resource-based theory and portfolio theory) to form new variables (for example, Anum \& Apriyanto, 2019; Apriyanto \& Anum, 2020; Apriyanto \& Nurhayaty, 2019; Hidayat et al., 2019).

The derivation of resource-based theory begins with the integration of two derived dimensions, resources and capabilities (Kerr et al., 2018). Ability has three aspects, namely emotional ability, physical ability, and intellectual ability, and what is derived from this path is physical ability. Physical ability has two aspects, viability and agility, and agility has three derived aspects: strategic speed, portfolio agility, and operational speed. Portfolio theory is divided into two approaches: diversification and investment focus, in derivatives into investment diversification.

\section{Discussion}

Companies that put innovation as a strategy in overcoming inclusion problems can focus on technical intelligence on handling investment diversification which is then proxied to improve their financial performance. In addition, the application of innovation is in the compliance mechanism in carrying out procedures during the change process. There are steps that have been prepared in dealing with environmental changes such as the availability of resources, accommodation of customer desires, service standards from the company, and the quality of service expected by customers and stakeholders (Evangelista and Vezzani, 2010; 
Jansen et al., 2006; Montalvan-Burbano et al., 2019). Many studies have been conducted, particularly on the relationship of organizational innovation to the impact of corporate financial performance. According to Camison and Villar-Lopez (2014), innovations built on the operational side can have an impact on internal management which directly affects the company's financial performance. Similarly, Narango Valencia et al., (2011), the position of operational innovation can be channeled into products, processes and management that affect the position of improvement on organizational performance (Ali et al., 2016; Ballot et al., 2015; Barroso Simao et al., 2016). The conclusion is that innovation is formed continuously on the company's financial performance (Al-Shammari et al., 2014).

In an ever-changing business environment, the effective adoption of new and evolving technologies is a determinant for the strength of a company. Technology is an important element that can be used to build innovation, create productive resources, and is one of the agility strategies as a company's efforts to improve performance (Fadil et al., 2016; Makkonen et al., 2016; Sutanto, 2017).

This innovation refers to the strength of internal processes to create new products which of course can provide solutions to inclusion problems that exist within the company. In research that has been carried out innovation in the field of technology helps companies reduce the level of asymmetry for a better level of financial performance (Laforet, 2013). In that sense, this research is contributed on the basis of innovation that leads to various investments that are tried to be carried out in developing banking financial performance.

Banking businesses can adopt innovations in technology to achieve financial performance goals in various operational efficiencies, quality control, learning, product and process innovation, or market development (Damanpour and Schneider, 2006). At a certain level, innovation can also be seen as a strategic tool in the efforts of banking financial performance. This strategy is certainly related to how a bank creates value, technology development, and competitive advantage (Hammel, 2009).

With the adoption of technological innovations, it causes changes in organizational movements that must be responded quickly in an effort to form a certain system for the creation of financial performance (Camison and Villar López, 2014). Organizational innovation developed by banking companies will be measured through timeliness, flexibility, and cost savings, as well as having a positive impact on the company's financial performance (Armbruster et al., 2008).

Several studies such as Damanpour and Schneider (2006); Damanpour et al., (2009); Aranz et al., (2019) showed that companies that carry out organizational transformation activities increase employee productivity by showing better company performance and can reduce administrative costs, purchase purchases, or increase employee satisfaction. This research has proven that organizational innovation as an agility strategy can have a good impact on a company's financial performance (Armbruster et al., 2008; Camison and Villar-López, 2014; Aranz et al., 2019).

Thus, when there is a problem with financial inclusion, companies such as banks are expected to carry out agility strategies that rely on innovations through new technology to improve their financial performance. Doan et al., (2020) who examined the effect of resource innovation as a proxy signal on the financial performance of commercial banks. The results showed that the signal generated from the innovation showed positive results. This result is particularly strong when large public banks comply with requirements or controls for homogeneity issues. The findings also confirm that the positive impact of this innovation signal has a direct impact on the financial performance of banks (Deephouse, 1997, 2000). 
In addition, the findings also expand existing knowledge about the relationship between signals generated from innovations and financial performance by confirming that there are two mediators that can be used to benefit from the contribution of these innovation signals (Deephouse, 1997, 2000). The first is to instill a feeling of trust in the company's efforts to minimize risk in ensuring the level of financial performance through the effectiveness of innovation as a signal of stakeholder behavior. Second, strong financial capabilities allow companies to be used as an indication that they are profitable or carry out more profitable business activities.

Research that can support the relationship between the level of innovation as a signal foundation on performance can be through asset channels, risk channels, and diversified investment income channels. Companies can make a good reputation in the media by improving the health of bank assets because bank managers are more adept at dealing with great pressure to keep bad debts at a low level. The effects transmitted through this reputation can have very variable results. When in transitional economic conditions, innovation can overcome problems indicated by reduced transparency and quality of information that can damage the bank's image in the minds of customers and investors.

Therefore, decisions about innovation in the field of channeling and raising investment, especially at the level of banking financial performance. In fact, as has been stated by academics about the implications of innovation as a signal to become an intangible asset and will always be developed into various situations of banking financial performance. This also applies to banks that have strong capital support in building innovation as a condition for the signal to be issued for even stronger financial performance advantages. This of course will make it very possible for the banking sector to exploit its agility strategy to strengthen its capital as a management of the bank's financial inclusion problems. Thus, the results of the study indicate that the interaction between different sources of information innovation affects bank performance by increasing trust between stakeholders.

The signal is said to be positive, if it can affect financial performance in improving future financial capabilities. Strong innovation support in turn can increase the contribution to the next financial performance signal. The combination of agility strategies from tangible resources: media reputation, intangible assets and financial capabilities can ensure the long-term business development of commercial banks. This study can have implications for future research directions using panel data from more banks and longer years in dealing with financial inclusion issues using signals obtained from innovations that are widely spread across various media and in delegating agility strategic diversification investment (ASDI) on the financial performance of commercial banks.

\section{Conclusion}

The problem of financial inclusion in the financial performance relationship of conventional banks can be solved by placing agility strategic diversification investment (ASDI) as a mediation. Financial inclusion which is seen as the exclusion of assets in a person can be parsed with agility strategies through innovations. Then these innovations can be used to differentiate investments in order to improve the financial performance of conventional banks through signals placed on the bank's reputation. 


\section{References}

[1] Afacan Findıkl1, M., Yozgat, U. and Rofcanin, Y.: Examining organizational innovation and knowledge management capacity the central role of strategic human resources practices (SHRPs)", Procedia - Social and Behavioral Sciences, Vol. 181, pp. 377-387, doi: 10.1016/j.sbspro. 2015.04.900. (2015).

[2] Ali, M., Seny Kan, K.A. and Sarstedt, M.: Direct and configurational paths of absorptive capacity and organizational innovation to successful organizational performance", Journal of Business Research, Vol. 69 No. 11, pp. 5317-5323, doi: 10.1016/j.jbusres.2016.04.131. (2016).

[3] Ali, A. E.: The challenges facing poverty alleviation and financial inclusion in North-East Kenya Province (NEKP), International Journal of Social Economics, Vol. 44, No. 12, pp. 2208-2223 (2019).

[4] Alshammari, A.A., Rasli, A., Alnajem, M. and Arshad, A.S.: An exploratory study on the relationship between organizational innovation and performance of non-profit organizations in Saudi arabia", Procedia - Social and Behavioral Sciences, Vol. 129, pp. 250-256, doi: 10.1016/j.sbspro.2014.03.674. (2014).

[5] Alvarado-Vargas, M.J. The mediating effect of innovation on the relationship between corporate reputation and performance in US firms", available at: http://digitalcommons.fiu.edu/ etd/927. (2013).

[6] Armbruster, H., Bikfalvi, A., Kinkel, S. and Lay, G.: Organizational innovation: the challenge of measuring non-technical innovation in large-scale surveys", Technovation, Vol. 28 No. 10, pp. 644657, doi: 10.1016/j.technovation.2008.03.003. (2008).

[7] Anderson, J. and Smith, G.: A great company can be a great investment", Financial Analysts Journal, Vol. 62 No. 4, pp. 86-93. (2006).

[8] Anum, A., and Apriyanto, S.: Detecting Gender'S Strategies in Learning Speaking. Premise: Journal of English Education, 8(1), 57. https://doi.org/10.24127/pj.v8i1.1932. (2019).

[9] Apriyanto, S., and Anum, A.: Personality of Politicians as the Object of Public Assessment. https://doi.org/10.4108/eai.20-9-2019.2290820. (2020).

[10] Apriyanto, S., and Nurhayaty, A.: Born In Social Media Culture: Personality Features Impact In Communication Context. Icollit, 167-175. icollit.ums.ac.id/2018. (2019).

[11] Arranz, N., Arroyabe, M.F., Li, J. and de Arroyabe, J.C.F.: An integrated model of organisational innovation and firm performance: generation, persistence and complementarity", Journal of Business Research, Vol. 105, pp. 270-282, doi: 10.1016/j.jbusres.2019.08.018 (2019).

[12] Camison, C. and Villar-Lopez, A.: Organizational innovation as an enabler of technological innovation capabilities and firm performance", Journal of Business Research, Vol. 67 No. 1, pp. 2891-2902, doi: 10.1016/j.jbusres.2012.06.004. (2014).

[13] Ballot, G., Fakhfakh, F., Galia, F. and Salter, A.: The fateful triangle: complementarities in performance between product, process and organizational innovation in France and the UK", Research Policy, Vol. 44 No. 1, pp. 217-232, doi: 10.1016/j.respol.2014.07.003. (2015).

[14] Barney, J.: Firm resources and sustained competitive advantage", Journal of Management Information Systems, Vol. 17 No. 1, pp. 99-120. (1991).

[15] Barroso Simao, L., Gouveia Rodrigues, R. and Madeira, M.J.: External relationships in the organizational innovation", RAI Revista de Administraç ao e Inovaç ao, Vol. 13 No. 3, pp. 156165, doi: 10.1016/j.rai.2016.06.002. (2016).

[16] Caruana, A., Vella, J., Konietzny, J. and Chircop, S.: Corporate greed: its effect on customer satisfaction, corporate social responsibility and corporate reputation among bank customers", Journal of Financial Services Marketing, Vol. 23 No. 4, pp. 226-233. (2018).

[17] Castilla-Polo, F., Gallardo-Vazquez, D., Sanchez-Hernandez, M.I. and Ruiz-Rodriguez, M.C.: An empirical approach to analyse the reputation-performance linkage in agrifood cooperatives", Journal of Cleaner Production, Vol. 195, pp. 163-175. (2018).

[18] Chen, T.J.: Corporate reputation and financial performance of life insurers", The Geneva Papers on Risk and Insurance - Issues and Practice, Vol. 41 No. 3, pp. 378-397. (2016).

[19] Cheston, S., Conte, T., Bykere, A. \& Rhyne, E.: The business of financial inclusion: Insights from banks in emerging markets. Accion: Center for Financial Inclusion. (2016). 
[20] Damanpour, F. and Schneider, M.: Phases of the adoption of innovation in organizations: effects of environment, organization and top managers 1", British Journal of Management, Vol. 17 No. 3, pp. 215-236. (2006).

[21] Damanpour, F., Walker, R.M. and Avellaneda, C.N.: Combinative effects of innovation types and organizational performance: a longitudinal study of service organizations", Journal of Management Studies, Vol. 46 No. 4, pp. 650-675, doi: 10.1111/j.1467-6486.2008.00814.x. (2009).

[22] Deephouse, D.L.: The effect of financial and media reputations on performance", Corporate Reputation Review, Vol. 1 No. 2, pp. 68-71. (1997).

[23] Deephouse, D.L.: Media reputation as a strategic resource: an integration of mass communication and resource-based theories", Journal of Management, Vol. 26 No. 6, pp. 1091-1112. (2000).

[24] Demirguc-Kunt, A., Klapper, L. and Randall, D.: Islamic finance and financial inclusion; measuring use of and demand for formal financial services among Muslim adults, Policy Research Working Paper No. WPS 6642, World Bank, Washington, DC, available at: http://documents.worldbank.org/curated/en/611351468337493348/pdf/WPS 6642. pdf (2013).

[25] Doan, N. T., Hoang, P.H., and Pham, A. H. T.: Media reputation: a source of banks' financial performance. International Journal of Bank Marketing Vol. 38 No. 6, pp. 1399-1419. (2020).

[26] Eberl, M. and Schwaiger, M.: Corporate reputation: disentangling the effects on financial performance", European Journal of Marketing, Vol. 39 Nos 7/8, pp. 838-54. (2005).

[27] Evangelista, R. and Vezzani, A.: The economic impact of technological and organizational innovations. A firm-level analysis", Research Policy, Vol. 39 No. 10, pp. 1253-1263, doi: 10.1016/j. respol.2010.08.004. (2010).

[28] Fadil, H., Singh, K. and Joseph, C.: The influence of organizational innovation towards internal service quality in MBKS", Procedia - Social and Behavioral Sciences, Vol. 224, pp. 317-324, doi: 10.1016/j.sbspro.2016.05.491. (2016).

[29] Fombrun, C.J. and Shanley, M.: What's in a name: reputation-building and corporate strategy", Academy of Management Journal, Vol. 33 No. 2, pp. 233-58. (1990).

[30] Fombrun, C.J., Ponzi, L.J. and Newburry, W.: Stakeholder tracking and analysis: the RepTrak ${ }^{\circledR}$ system for measuring corporate reputation", Corporate Reputation Review, Vol. 18 No. 1, pp. 3-24. (2015).

[31] Fombrun, C.J.: Corporate reputation as economic assets", in Hitt, M.A., Freeman, R.E. and Harrison, J.S. (Eds), The Blackwell Handbook of Strategic Management, Blackwell Publishers, Malden. (2001).

[32] Hamel, G.: Management innovation”, Leadership Excellence, Vol. 26 No. 5, p. 5. (2009).

[33] Hall, E.H. and Lee, J.: Assessing the impact of firm reputation on performance: an international point of view", International Business Research, Vol. 7 No. 12, pp. 1-13. (2014).

[34] Hartono, S. B., Hajar, I., Ristianawati, Y., and Budiarto, A.: ISFA-As Intervening Financial Literacy and Culture towards Organisational Financial Performance: A Transformational Leadership Approach. International Journal of Innovation, Creativity and Change, Vol 8, No. 6, pp. 47-66 (2019).

[35] Hassan, R., Karmakar, G., Kamruzzaman, J. and Srinivasan, B.: A comprehensive spectrum trading scheme based on market competition, reputation and buyer specific requirements", Computer Networks, Vol. 84, pp. 17-31. (2015).

[36] Hidayat, O., Apriyanto, S., Program, P., Science, A., Tun, U., and Onn, H.: Drama Excerpt : Tool in Enhancing Speaking Ability for Junior High School. 2(3), 1-9. (2019).

[37] Hofer, C.W. and Schendel, D.: Strategy Formulation: Analytical Concepts, West Publ (1978).

[38] Inglis, R., Morley, C. and Sammut, P.: Corporate reputation and organisational performance: an Australian study", Managerial Auditing Journal, Vol. 21 No. 9, pp. 934-947. (2006).

[39] Jansen, J.J.P., Van den Bosch, F.A.J. and Volberda, H.W.: Exploratory innovation, exploitative innovation, and performance: effects of organizational antecedents and environmental moderators", Management Science, Vol. 52, pp. 1661-1674. (2006).

[40] Laforet, S.: Organizational innovation outcomes in SMEs: effects of age, size, and sector", Journal of World Business, Vol. 48 No. 4, pp. 490-502, doi: 10.1016/j.jwb.2012.09.005. (2013).

[41] Kaur, A. and Singh, B.: Re-examining reputation-performance liaison in Indian context", Business Perspectives and Research, Vol. 6 No. 2, pp. 100-112. (2018). 
[42] Lamb, R.: Competitive Strategic Management, Prentice Hall (1984).

[43] Liu, L., Li, Q., Xu, Y. and Zhang, Y.: Firm celebrity, reputation and performance: a social media perspective", Pacific Asia Conference on Information Systems (PACIS) (2014).

[44] Makkonen, H., Johnston, W.J. and Javalgi, R.G. (2016), "A behavioral approach to organizational innovation adoption", Journal of Business Research, Vol. 69 No. 7, pp. 2480-2489, doi: 10.1016/j.jbusres.2016.02.017.

[45] Montalvan-Burbano, N., Plaza-Ubeda, J.A., Perez-Valls, M. and Sabando-Vera, D.: Dataset on organizational innovation and its determinants in the SMEs hotels", Data Brief, Vol. 26, 104352, doi: 10.1016/j.dib.2019.104352. (2019).

[46] Phillips, P., Zign, K., Santos, M.M. and Schegg, R.: The interactive effects of online reviews on the determinants of Swiss hotel performance: a neural network analysis", Tourism Management, Vol. 50, pp. 130-141. (2015).

[47] Podony, J.: A status-based model of market competition", American Journal of Sociology, Vol. 98 No. 4, pp. 829-72. (1993).

[48] Porter, M.E.: Generic Competitive Strategies, Competitive Strategy, Free Press, New York. (1980).

[49] Porter, M.E. and Advantage, C.: Creating and sustaining superior performance, Competitive Advantage, Vol. 167, pp. 167-206 (1985).

[50] Raithel, S. and Schwaiger, M.: The effects of corporate reputation perceptions of the general public on shareholder value", Strategic Management Journal, Vol. 36 No. 6, pp. 945-956. (2015).

[51] Ristianawati Y., Ghoniyah N., and Hartono, S.B.: Strategic Agility Diversification Investment: Islamic Financial Inclusion on the Financial Performance of Sharia Banks, Annals of R.S.C.B., Vol 4, No. 4, pp. 2937-2945. (2021).

[52] Roberts, P. and Dowling, G.: Corporate reputation and sustained superior financial performance", Strategic Management Journal, Vol. 23, pp. 1077-93. (2002).

[53] Rose, C. and Thomsen, S.: The impact of corporate reputation on performance: some Danish evidence", European Management Journal, Vol. 22 No. 2, pp. 201-210. (2004).

[54] Sariol, A.M. and Abebe, M.A.: The influence of CEO power on explorative and exploitative organizational innovation", Journal of Business Research, Vol. 73, pp. 38-45, doi: 10.1016/j.jbusres.2016.11.016. (2017).

[55] Sarma, M.: Index of financial inclusion. Indian Council for Research and Economic Relations Working Paper No. 215. New Delhi, India. (2008).

[56] Santiago, A., Pandey, S. and Manalac, M.T.: Family presence, family firm reputation and perceived financial performance: empirical evidence from the Philippines", Journal of Family Business Strategy, Vol. 10 No. 1, pp. 49-56. (2019).

[57] Shahid, Y., Felix, M., Gunasekaran, A. and James, C.S.: A study of competitive strategy, organisational innovation and organisational performance among Australian manufacturing companies", International Journal of Production Economics, Vol. 52, pp. 161-172 (1997).

[58] Shapiro, C.: Premiums for high quality products as returns to reputations", Quarterly Journal of Economics, Vol. 98 No. 4, pp. 659-79. (1983).

[59] Sutanto, E.M.: The influence of organizational learning capability and organizational creativity on organizational innovation of Universities in East Java, Indonesia”, Asia Pacific Management Review, Vol. 22 No. 3, pp. 128-135, doi: 10.1016/j.apmrv.2016.11.002. (2017).

[60] Tallon, P. and Pinsonneault, A.: Competing perspectives on the link between strategic information technology alignment and organizational agility: insights from a mediation model”, MIS Quarterly, Vol. 35 No. 2, doi: 10.2307/23044052 (2011).

[61] Tischer, S. and Hildebrandt, L. Linking corporate reputation and shareholder value using the publication of reputation rankings", Journal of Business Research, Vol. 67, pp. 1007-1017 (2014).

[62] Wong, T.C., Wong, S.Y. and Chin, K.S.: A neural network-based approach of quantifying relative importance among various determinants toward organizational innovation, Expert Systems with Applications, Vol. 38 No. 10, pp. 13064-13072, doi: 10.1016/j.eswa.2011.04.113. (2011).

[63] World Bank: Global findex surveys. Washington, DC. (2014, 2017). 